\title{
Application of Plant Biotechnology in Improvement of Vegetable Breeding
}

\author{
Vaibhav Singh ${ }^{1} *$, Kumari Shikha ${ }^{2}$, Saurabh Singh ${ }^{1}$, \\ Aniruddh Pratap Singh $^{3}$ and Deepak Kumar Jaiswal ${ }^{4}$
}

\author{
${ }^{1}$ Department of Horticulture, ${ }^{2}$ Department of Genetics \& Plant Breeding, ${ }^{3}$ Nalanda College of \\ Horticultue, ${ }^{4}$ Department of Entomology \& Agricultural, Zoology, IAS, \\ BHU, Varanasi-221005, India \\ *Corresponding author
}

\section{A B S T R A C T}

\begin{tabular}{|l|}
\hline Ke y w or d s \\
Antioxidants, \\
Biotechnology, \\
Minerals, \\
Vegetables, \\
Vitamins etc \\
\hline Article Info \\
\hline $\begin{array}{l}\text { Accepted: } \\
12 \text { March } 2019 \\
\text { Available Online: } \\
\text { 10 April } 2019\end{array}$ \\
\hline \hline
\end{tabular}

\section{Keywords}

\section{Introduction}

The advent of modern biotechnology furnishes a new track of breeding vegetable crops. The term biotechnology defined as a group of technologies that employ biological entities or processes to create new and useful products and processes. It is gaining importance in breeding of vegetable plants to accomplish new varieties with high and stable yield, good quality, as well as pest and stress resistance. It has been suggested that the history of plant biotechnology could be traced
The advent of modern biotechnology furnishes a new track of breeding vegetable crops. The term biotechnology defined as a group of technologies that employ biological entities processes to create new and useful products and processes. It is being used to address problems in areas of vegetable production and processing. It was estimated that 2.6 million deaths worldwide and $31 \%$ of cardiovascular diseases may be attributed to inadequate consumption of fruit and vegetables according to WHO reports, 2002. Vegetables thus play vital role in ensuring good health as it is rich source of vitamins, minerals, antioxidants and dietary fibres. Plant biotechnology has been used to raise and stabilize yields of vegetables; to improve resistance to pests, diseases and abiotic stresses such as do enhance the nutritional content of foods. In this paper, we application application of modern biotechnology in vegetable breeding research. Plant biotechnology has successfully revolutionised the field of biology and molecular breeding, which is accompanied by enhanced productivity and quality of vegetable crops. 
chrysanthemum an insecticide in China etc. However, the era of plant biotechnology is known to begin in the early 1980 s with the mear stone reports of developing transgenic plants using Agrobacterium tumefaciens [5, 6, 7 and 8]. The commercialization of transgenic crops revealed the successful integration of biotechnology into plant breeding and crop improvement programs by 1996 [9].

It was estimated that 2.6 million deaths worldwide and $31 \%$ of cardiovascular diseases may be attributed to inadequate consumption of fruit and vegetables according to WHO reports, 2002[10]. Vegetables play an important role in human nutrition, being mostly low in fat and carbohydrates, but rich in vitamins, minerals, antioxidants and dietary fibres. By using conventional breeding several high yielding hybrid cultivars of different vegetable crops have been developed.

But, it require many generations to get the desired combination of traits, and long-time lags restrict its further prospects, especially for perennial crops such as trees and some species of livestock. Such kind of selection based on the phenotype render a slow, demanding process and also expensive in terms of both time and money. Under such circumstances modern biotechnology proved an efficient tool in supplementing the conventional breeding methods of research and subsequently resulted in quantum jump in the improvement of productivity and nutritional quality of vegetable crops.

Biotechnology is interdisciplinary field which is related to many facets of lives, particularly with global warming, genetically modified drugs, food and energy production. It has been used to develop low-cost disease-free planting materials for crops such as cassava, banana and potato through meristem culture and long-term conservation of genetic resources through cryopreservation. Plant biotechnology not only accelerated the vegetable breeding programme but also extended the range of traits that can be addressed. By using biotechnological approaches, limitations of conventional breeding such as problem of linkage drag, sexual barrier in wide crosses, anti-nutritional factor etc. can be overcome efficiently and effectively. Recent developments in molecular biology such as in-vitro mutagenesis, genetic engineering (Cisgenesis, transgenic and intragenesis), DNA sequencing, cloning, molecular marker etc. foster new meaning, new dimension, and new potential to old biotechnology. It also provided new perspectives of microbial intervention in agricultural practices, such as bio-fertilizers, bio-control agents, and various microbiological products used in modern agriculture [11]. Thus, modern biotechnology approaches can have a dramatic effect on the improvement of vegetable crops.

\section{Biotechnological approaches}

Various biotechnological approaches have been utilized to ameliorate vegetable quality and quantity. Scientists are successful in isolating target gene of interest, its transfer and integration into the host species based on the knowledge of DNA. Plant biotechnology enables amelioration that is not possible with traditional crossing of related species alone. Such approaches have been concisely discussed below.

\section{Genetic engineering}

Modern Genetic engineering has the potential to ameliorate quality, productivity and values to vegetable crops. It involves the modification of genetic material of the host plant by introducing new genes for improved agronomic performance and/or enhanced nutrition to provide GM crops which are 
under commercial cultivation in many countries [12]. Genetic engineering has also helped immensely in creation of vegetable crops with various beneficial and development traits like flavours and aromas, sizes, harvest durability, colours, tastes, resistance etc.

\section{Molecular markers}

Molecular markers directly reveal the polymorphism at the level of DNA and utilized in creation of high-resolution genetic maps and genetic linkage between markers and important crop traits have been exploited for improvement of vegetable breeding [13, 14].

Such molecular marker technique have been utilized for identification for vegetable varieties or cultivars such as in tomato [15], potato [16], onion, garlic, and related species [17] etc. Various molecular markers such as RFLP, RAPD, AFLP, SSR, ESTs, SNPs etc. are used for development of saturated genetic maps; DNA fingerprinting; phylogenetic and evolutionary studies; heterotic breeding; gene tagging and marker assisted selection (MAS).

\section{Cryopreservation}

Application of biotechnological processes has a promising role in conservation of germplasm. Cryopreservation is one of the biotechnological tool which involves storage of germplasm at an ultralow temperature, typically that of liquid nitrogen $\left(-196^{\circ} \mathrm{C}\right)$. It provides the prospect of storage for indefinite periods with minimal risk. Schemske et al., (1994) reported that the cryopreservation, tissue, organ culture, micro-propagation techniques, germplasm banking, gene banking, applied advanced research have been used to introduce new genetic modification in the existing population, reinforcement of existing population and reintroduction into the wild controlled environments [18].

\section{Tissue culture}

Tissue culture refers to the regeneration of plants in the in-vitro condition from diseasefree plant parts. This technique allows production of clones of a plant in a method known as micro-propagation. Examples of crops produced using tissue culture include citrus, pineapples, avocados, mangoes, bananas, coffee and papaya.

\section{In-vitro mutagenesis}

Genetic variability of vegetables could be increased by mutation. Mutations can occur spontaneously in the nature or induced artificially by using either chemical or physical mutagens which leads to sudden heritable change in the genotype of the plant.

Induced mutations have been used mainly to improve particular characters such as earliness, semi-dwarfness, lodging resistance, disease resistance, higher yield and better quality in well-adapted local varieties or to generate variation difficult to be found in germplasm collections. Induced mutagenesis foster easier and rapid identification of location of genes on the chromosomes, study of gene structure, expression and regulation, and exploration of genomes.

\section{Double haploids}

It involves techniques like anther and microspore cultures, wide hybridisation, ovary and ovule cultures that have been utilised in a range of economically important vegetable crop species. production of doubled haploids (DHs) is also dependent on totipotency of plants, i.e. whole plant arising from the doubling of chromosome number of gametic cells, pollens and egg cells, prior to their regeneration $[19,20]$. By using this technique, homozygous individuals could be produced quite routinely [21]. 
Table.1 Application of various biotechnology in improving relevant traits in vegetables

\begin{tabular}{|c|c|c|c|}
\hline $\begin{array}{l}\text { Biotechnological } \\
\text { approach }\end{array}$ & Crops & Trait of interest & Reference \\
\hline \multirow{3}{*}{$\begin{array}{l}\text { Genetic } \\
\text { engineering }\end{array}$} & Potato & Potato tuber moth resistant gene $C r y l A b$ & Kumar et al., 2010 [22] \\
\hline & Lettuce & Salt resistance & Park et al., 2005 [23] \\
\hline & $\begin{array}{l}\text { Flavr Savr } \\
\text { tomato }\end{array}$ & $\begin{array}{l}\text { suppression of the tomato polygalacturonase }(P G) \\
\text { gene, }\end{array}$ & Sheehy et al., 1988 [24] \\
\hline \multirow[t]{3}{*}{ Molecular marker } & \multirow[t]{3}{*}{ Tomato } & $\begin{array}{l}\text { More than } 40 \text { genes that confer resistance to major } \\
\text { classes of tomato pathogens have been mapped, } \\
\text { cloned, and/or sequenced }\end{array}$ & Grube et al., 2000 [25] \\
\hline & & Resistant to Meloidogyne incognita & $\begin{array}{l}\text { Williamson et al., } 1994 \\
\text { [26] }\end{array}$ \\
\hline & & tomato mosaic virus resistance & Sobir et al., 2000 [27] \\
\hline $\begin{array}{l}\text { In-vitro } \\
\text { mutagenesis }\end{array}$ & Potato & Salt resistant & Ochattet al., 1998 [28] \\
\hline \multirow[t]{12}{*}{ Tissue culture } & Tomato & $\begin{array}{l}\text { Fusarium R, variety DNAP-17 } \\
\text { High solid contents var DNAP9 }\end{array}$ & $\begin{array}{l}\text { Evans, } 1989[29] \\
\text { Evans, } 1989[29]\end{array}$ \\
\hline & Brassica juncea & $\begin{array}{l}\text { High yield, shattering resistant, cv released Pusa Jai } \\
\text { Kisan }\end{array}$ & $\begin{array}{l}\text { Katiyar and Chopra, } 1995 \\
\text { [30] }\end{array}$ \\
\hline & Capsicum & yellow fruit, cv Bell sweet & Morrison et al., 1989 [31] \\
\hline & & early maturing and high yielding, cv A-D4' & Xu and Chen, 1995 [32] \\
\hline & Sweet potato & cultivar Scarlet & $\begin{array}{l}\text { Moyer and Collins, } 1983 \\
\text { [33] }\end{array}$ \\
\hline & Tobacco & Atrazine, amitrole, paraquat resistant & Jain et al., 1998 [34] \\
\hline & Brassica & Atrazine, phenmedipham resistance & Jain et al., 1998 [34] \\
\hline & Tomato & Clavibactermichiganense & Sotirova et al., 1999; [35] \\
\hline & \multirow[t]{2}{*}{ Potato } & Fusarium solani resistance & Jain et al., 1998 [34] \\
\hline & & $\begin{array}{l}\text { F. oxysporum, Phytophthorainfestans, Alternaria } \\
\text { solani, potato leaf roll luteo virus }\end{array}$ & $\begin{array}{l}\text { Cristinzeo\&Testa, } 1999 \\
\text { [36] }\end{array}$ \\
\hline & Brassica & Marsh grass salt tolerance & $\begin{array}{l}\text { Kirti et al., } 1991 \quad[37] \text {; } \\
\text { Jain et al., } 1990 \text { [34]; } \\
\text { Seliskar\& } \\
2000[38]\end{array}$ \\
\hline & Tobacco, tomato & Salt tolerance & $\begin{array}{l}\text { Remotti, } 1998 \\
\text { [39]Boscherini et al., } \\
\text { 1999[40] }\end{array}$ \\
\hline
\end{tabular}

\section{Application of biotechnology in improving} relevant traits in vegetable

Several traits have been incorporated to relevant crops by biotechnological approaches. These species include potato, tomato, Brassica spp., sweet potato, cassava etc.

In 1990, the first food product of biotechnology (an enzyme used in cheese production and yeast used for baking) was 
made available in the market. Almost one third of the global biotech crop area was grown in developing countries. Some examples reported in the literature are described below (Table 1).

Merits of plant biotechnology in improvement of vegetable breeding

- Safe to use.

- The agriculture advancements resulted in sustainable improvements in agronomic traits of crops such as disease resistance and drought tolerance. In addition to this, plants can now be utilized for biofuel production, phytoremediation, the amelioration of nutritional values in edible plants, the identification of compounds for medicinal purposes in plants and the use of plants as therapeutic protein production platforms such as hirudin (anti-thrombin protein).

- The diversification of plant breeding has resulted in great abundance of new patents issued in these fields and, as many of these inventions approach commercial realization, the subsequent increase in agriculturallybased industries [41].

- Modern agriculture practices furnish large production at the affordable price thus help in ensuring food security.

- Study of gene expression become feasible using novel technologies, such as microarrays and DNA chips [42].

\section{Limitations}

- Foreign genes are reported to alter the nutritional value of foods in unpredicted manner.

- Many genetically engineered foods are known to be derived from microorganisms, whose allergenic potential are either unknown or untested. So there is chance of transfer of allergen properties to GM crops.

- There is possibility of emergence of new super weeds due to cross pollination of GM crops (genetically modified crops) having herbicide and insect resistance with wild species.

- Commercialization of transgenic crops may pose a threat to genetic diversity of crops already endangered by current agricultural practices that favour the worldwide adoption of a few crop varieties.

- Some critics of genetic modification claim that patenting allows inventor to have monopoly control of genetically modified plants or animals.

- Organic farmers fear that one day GM foods would be difficult to be distinguished from non-GM crops as it lacks labelling.

In conclusion, the above review emphasizes that plant biotechnology has revolutionised the field of biology and molecular breeding, which is accompanied by increased productivity and quality of vegetable crops. Such interdisciplinary science requires knowledge of the genomics, transcriptomics and proteomics, a solid foundation in statistical software to estimate genetic effects, strong background in plant biology, experience with both the laboratory methods of molecular biology/functional genomics and field-based breeding practices, and the ability to manage large datasets with diverse data types. To ensure continuous rapid growth of plant biotechnology, plant biotechnologists are required to translate this knowledge into pragmatic applications, especially those that directly benefit the consumers.

\section{References}

1. Schleiden, M. J. (1838). Einigebemerkungenuber den vegetabilischenfaserstoff und sein 
verhaltnisszumstarkemehl. Annalen der Physik, 119(2), 391-398.

2. Schwann, T. (1839). Mikroskopische untersuchungenuber die ubereinstimmung in der struktur und demwachstum der tiere und pflanzen. Berlin, Germany: Verlag der Sander schenBuchhandlung Google Scholar.

3. Virchow, R. (1858). Ueber die natur der constitutionell-syphilitisc henaffectionen. Archiv fur pathologische Anatomie und Physiologie und fur klinische Medicin, 15(3-4), 217-336.

4. Vasil, I. K. (2008). A history of plant biotechnology: from the cell theory of Schleiden and Schwann to biotech crops. Plant cell reports, 27(9), 1423.

5. Bevan, M. W., Flavell, R. B. and Chilton, M. D. (1983). A chimaeric antibiotic resistance gene as a selectable marker for plant cell transformation. Nature, 304(5922), 184.

6. Fraley, R. T., Rogers, S. G., Horsch, R. B., Sanders, P. R., Flick, J. S., Adams, S. P. and Galluppi, G. R. (1983). Expression of bacterial genes in plant cells. Proceedings of the National Academy of Sciences, 80(15), 4803-4807.

7. Herrera-Estrella, L., Depicker, A., Van Montagu, M. and Schell, J. (1983). Expression of chimaeric genes transferred into plant cells using a Ti-plasmid-derived vector. Nature, 303(5914), 209.

8. Moose, S. P. and Mumm, R. H. (2008). Molecular plant breeding as the foundation for 21st century crop improvement. Plant physiology, 147(3), 969-977.

9. Delannay, X., Bauman, T. T., Beighley, D. H., Buettner, M. J., Coble, H. D., De Felice, M. S. and Hancock, F. G. (1995). Yield evaluation of a glyphosate-tolerant soybean line after treatment with glyphosate. Crop Science, 35(5), 14611467.
10. World Health Organization. (2002). Theworld health report 2002: reducing risks, promoting healthy life. World Health Organization.

11. Tengerdy, R. P. and Szakacs, G. (1998). Perspectives in agrobiotechnology. Journal of biotechnology, 66(2-3), 91-99.

12. James, C. (2011). Global status of commercialized biotech/GM crops, 43. Ithaca, NY: ISAAA.

13. Edwards, M. D., Stuber, C. W. and Wendel, J. F. (1987). Molecular-markerfacilitated investigations of quantitativetrait loci in maize. I. Numbers, genomic distribution and types of gene action. Genetics, 116(1), 113-125.

14. Paterson, A. H., Lander, E. S., Hewitt, J. D., Peterson, S., Lincoln, S. E. and Tanksley, S. D. (1988). Resolution of quantitative traits into Mendelian factors by using a complete linkage map of restriction fragment length polymorphisms. Nature, 335(6192), 721.

15. Noli, E., Conti, S., Maccaferri, M. and Sanguineti, M. C. (1999). Molecular characterization of tomato cultivars. Seed Science and Technology, 27(1), 1-10.

16. Ashkenazi, V., Chani, E., Lavi, U., Levy, D., Hillel, J. and Veilleux, R. E. (2001). Development of microsatellite markers in potato and their use in phylogenetic and fingerprinting analyses. Genome, 44(1), 50-62.

17. Fischer, D. and Bachmann, K. (2000). Onion microsatellites for germplasm analysis and their use in assessing intraand interspecific relatedness within the subgenus Rhizirideum. Theoretical and Applied Genetics, 101(1-2), 153-164.

18. Schemske, D. W., Husband, B. C., Ruckelshaus, M. H., Goodwillie, C., Parker, I. M. and Bishop, J. G. (1994). Evaluating approaches to the conservation of rare and endangered plants. Ecology, 75(3), 584-606. 
19. Forster, B. P., Heberle-Bors, E., Kasha, K. J. and Touraev, A. (2007). The resurgence of haploids in higher plants. Trends in plant science, 12(8), 368-375.

20. Jauhar, P. P., Xu, S. S. and Baenziger, P. S. (2009). Haploidy in cultivated wheats: induction and utility in basic and applied research. Crop science, 49(3), 737-755.

21. Kasha, K. J. (2005). Chromosome doubling and recovery of doubled haploid plants. In Haploids in crop improvement II(pp. 123-152). Springer, Berlin, Heidelberg.

22. Kumar, M., Chimote, V., Singh, R., Mishra, G. P., Naik, P. S., Pandey, S. K. and Chakrabarti, S. K. (2010). Development of $\mathrm{Bt}$ transgenic potatoes for effective control of potato tuber moth by using cry1 Ab gene regulated by GBSS promoter. Crop Protection, 29(2), 121127.

23. Park, B. J., Liu, Z., Kanno, A. and Kameya, T. (2005). Increased tolerance to salt-and water-deficit stress in transgenic lettuce (Lactucasativa L.) by constitutive expression of LEA. Plant growth regulation, 45(2), 165-171.

24. Sheehy, R. E., Kramer, M. and Hiatt, W. R. (1988). Reduction of polygalacturonase activity in tomato fruit by antisense RNA. Proceedings of the National Academy of Sciences, 85(23), 8805-8809.

25. Grube, R. C., Radwanski, E. R. and Jahn, M. (2000). Comparative genetics of disease resistance within the Solanaceae. Genetics, 155(2), 873-887.

26. . Williamson, V. M., Ho, J. Y., Wu, F. F., Miller, N. and Kaloshian, I. (1994). A PCR-based marker tightly linked to the nematode resistance gene, $\mathrm{Mi}$, in tomato. Theoretical and Applied Genetics, 87(7), 757-763.

27. Ohmori, T., Murata, M. and Motoyoshi, F. (2000). Molecular characterization of the SCAR markers tightly linked to the
Tm-2 locus of the genus Lycopersicon. Theoretical and Applied Genetics, 101(12), 64-69.

28. Ochatt, S. J., Marconi, P. L., Radice, S., Arnozis, P. A. and Caso, O. H. (1998). In vitro recurrent selection of potato: production and characterization of salt tolerant cell lines and plants. Plant Cell, Tissue and Organ Culture, 55(1), 1.

29. Evans, D. A. (1989). Somaclonal variation-genetic basis and breeding applications. Trends in Genetics, 5, 46-50.

30. Katiyar, R. K. and Chopra, V. L. (1995). A somaclone of Brassica juncea is processed into a variety and is released for commercial cultivation in India. Cruciferae Newslett, 17, 92-93.

31. Morrison, R. A. and Loh, W. H. T. (1989). Tissue culture of tomato and pepper: new tools for plant breeding Tomato and pepper production in the Tropics. In International Symposium on Integrated Management Practices 21-26 Mar 1988Tainan (Taiwan). Asian Vegetable Research and Development Center, Shanhua (Taiwan).

32. Xu, Z., and Chen, Z. (1995). Recent advances of plant tissue culture and biotechnology in China. Plant Tissue Culture \& Biotech, 1, 147-153.

33. Moyer, J. W., and Collins, W. W. (1983). 'Scarlet'sweet potato [Ipomoea batatas, cultivar]. HortScience.

34. Brar, D., and Jain, S. M. (1998). Somaclonal variation: mechanism and applications in crop improvement. In Somaclonal variation and induced mutations in crop improvement (pp. 1537). Springer, Dordrecht.

35. Sotirova, V., Shtereva, L., Zagorska, N., Dimitrov, B. and Bogatsevska, N. (1999). Resistance responses of plants regenerated from tomato anther and somatic tissue cultures to Clavibacter michiganense subsp. michiganense. Israel 
Journal of Plant Sciences, 47(4), 237243.

36. Cristinzio, G. and Testa, A. (1999). In vitro evaluation of resistance of potato cultivars to Phytophthora infestans. Potato research, 42(1), 101-105.

37. Kirti, P. B., Hadi, S., Kumar, P. A. and Chopra, V. L. (1991). Production of sodium-chloride-tolerant Brassica juncea plants by in vitro selection at the somatic embryo level. Theoretical and applied genetics, 83(2), 233-237.

38. Seliskar, D. M. and Gallagher, J. L. (2000). Exploiting wild population diversity and somaclonal variation in the salt marsh grass Distichlisspicata (Poaceae) for marsh creation and restoration. American Journal of Botany, 87(1), 141-146.

39. Remotti, P. C. (1998). Somaclonal variation and in-vitro selection for crop improvement. In Somaclonal Variation and Induced Mutations in Crop Improvement (pp. 169-201). Springer, Dordrecht.

40. Boscherini, G., Muleo, R., Montagni, G., Cinelli, F., Pellegrini, M. G., Bernardini, M. and Buiatti, M. (1999). Characterization of salt tolerant plants derived from a Lycopersicon esculentum Mill. somaclone. Journal of plant physiology, 155(4-5), 613-619.

41. L Hefferon, K. (2010). Plant biotechnology patents: applications in agriculture and medicine. Recent patents on biotechnology, 4(2), 136-152.

42. Schaffer, R., Landgraf, J., Perez-Amador, M. and Wisman, E. (2000). Monitoring genome-wide expression in plants. Current opinion in Biotechnology, 11(2), 162-167.

\section{How to cite this article:}

Vaibhav Singh, Kumari Shikha, Saurabh Singh, Aniruddh Pratap Singh and Deepak Kumar Jaiswal. 2019. Application of Plant Biotechnology in Improvement of Vegetable Breeding. Int.J.Curr.Microbiol.App.Sci. 8(04): 1428-1435. doi: https://doi.org/10.20546/ijcmas.2019.804.166 